\title{
Binding of Nonmucoid Pseudomonas aeruginosa to Normal Human Intestinal Mucin and Respiratory Mucin from Patients with Cystic Fibrosis
}

\author{
U. Sajjan, J. Reisman, P. Doig, ${ }^{*}$ R. T. Irvin, ${ }^{\star}$ G. Forstner, and J. Forstner \\ Hospital for Sick Children and University of Toronto, Toronto, Ontario, Canada M5G 1X8; *Department of Biochemistry, University of \\ Victoria, British Columbia, Canada V8W 2Y2; and ${ }^{\ddagger}$ Department of Microbiology, University of Alberta, Edmonton, Canada T6G $2 H 7$
}

\begin{abstract}
Lung infections due to Pseudomonas aeruginosa and Pseudomonas cepacia are common in patients with cystic fibrosis. Initial colonization is due to nonmucoid $P$. aeruginosa, while later mucoid variants emerge and are associated with chronic infection. $P$. cepacia colonization tends to be more prevalent in older patients. The present study was conducted to discover whether highly purified mucins (from cystic fibrosis sputum and control intestinal secretions) exhibited specific binding of nonmucoid $P$. aeruginosa. In vitro solid phase microtiter binding assays (with or without a blocking agent) as well as solution phase assays were conducted. Bacteria bound to both mucins via bacterial pili, but no differences in binding capacity were noted between the mucins. Unlike $P$. cepacia (described in the accompanying manuscript) there was also no preferential binding of $P$. aeruginosa to mucins versus bovine serum albumin, casein, gelatin, or a host of structurally unrelated proteins and glycoproteins. Carbohydrate hapten inhibition studies did not suggest the existence of specific mucin carbohydrate receptors for $P$. aeruginosa. In solid phase assays a low concentration $(0.05$ M) of tetramethylurea abolished $\boldsymbol{P}$. aeruginosa bacterial binding to both mucins as well as to BSA, whereas in solution phase assays mucin binding to bacteria was not completely disrupted by tetramethylurea. Specific monoclonal antipilus antibodies did not inhibit binding to a greater extent than did Fab fragments of normal mouse IgG. Binding of strains PAO1 and PAK (and isolated PAK pili) to buccal epithelial cells was not influenced by the presence of mucin in binding assay mixtures.

Our findings do not support the widely held notion that specific mucin receptors are responsible for the attachment of $P$. aeruginosa pili, nor do they support the idea that there is a competitive interference by mucins of bacterial binding to respiratory cells. In patients with cystic fibrosis, it would seem unlikely therefore that initial colonization of the lungs by $P$. aeruginosa is due to a 'selective tropism' of these bacteria for respiratory mucin. (J. Clin. Invest. 1992. 89:657-665.) Key words: Pseudomonas aeruginosa binding • mucus glycoproteins • cystic fibrosis • pili • epithelial cell

\section{Introduction}

Patients with cystic fibrosis exhibit generalized mucus obstruction and, in the airways, impaired mucociliary clearance and

Address correspondence to Janet Forstner, M.D., Ph.D., The Hospital for Sick Children, 555 University Avenue, Room 3423, Toronto, Ontario, Canada M5G 1 X8.

Received for publication 21 December 1990 and in revised form 7 June 1991.

J. Clin. Invest.

(c) The American Society for Clinical Investigation, Inc. 0021-9738/92/02/0657/09 \$2.00

Volume 89, February 1992, 657-665 colonization with Pseudomonas aeruginosa. The initial colonization is with nonmucoid $P$. aeruginosa, while later, variants expressing a mucoid form emerge and are associated with chronic pulmonary infection. Little is known about the selective bacterial-host interactions which establish the initial colonization, although in vitro studies have demonstrated the adherence of nonmucoid $P$. aeruginosa to respiratory epithelial cells, and the involvement of bacterial pili as adhesins (1-4). Pilin proteins have been isolated and sequenced from well characterized nonmucoid strains PAOI and PAK, and the binding domains localized to $\mathrm{COOH}$-terminal regions of the proteins $(3,4)$. Monoclonal antibodies against specific $\mathrm{COOH}-$ terminal domains (e.g., PK34C for PAK pili) effectively inhibit PAO1 and PAK pili binding to buccal cells (4). Much less is known, however, concerning epithelial cell receptors for $P$. aeruginosa, although suggestions have been made that cell surface glycolipids and/or glycoproteins may be important for the binding of Pseudomonas pili. Krivan et al. (5) reported that $P$. aeruginosa bind to $N$-acetylgalactosamine (GalNAc) ${ }^{1} \beta 1,4$ galactose $(\mathrm{Gal})$ sequences of asialo-GM1 and asialo-GM2 gangliosides. Baker et al. (6) have also shown positive binding to $\mathrm{Gal} \beta$ 1,4 glucose (Glc) $\beta$ 1-Ceramide, whereas Doig et al. (7) suggest a role for one or more cell surface glycoproteins as receptors.

Although respiratory cells bind $P$. aeruginosa in vitro, some doubts about the relative importance in vivo of bacterial-cell interactions have been raised. For example, immunohistopathological studies of Baltimore et al. (8) have demonstrated that in autopsy specimens of cystic fibrosis (CF) lungs, $P$. aerugin$o s a$ are almost always found associated with stagnant luminal mucus and exudates rather than attached to mucosal surfaces. Nelson et al. (9) have shown adherence in vitro of $P$. aeruginosa to mucin monolayers, and Plotkowski et al. (10) employing a frog palate model, found that $P$. aeruginosa $a$ attached preferentially to serosal rather than mucosal surfaces, and to patches of luminal mucus rather than to mucosal cell surfaces.

In vitro microtiter well binding assays by Viswanath and Ramphal $(11,12)$ and Ramphal et al. (13) have demonstrated adherence of piliated $P$. aeruginos $a$ to preparations of respiratory mucin, an association that they suggest depends upon specific carbohydrate receptor sites in respiratory mucins. They have also reported that mucins interfere with the binding of these bacteria to respiratory cells; and on this basis, propose that the association between $P$. aeruginosa and mucin is specific, and that mucin represents the preferential colonization site in the airways of patients with cystis fibrosis.

Although these are attractive proposals, they have been somewhat difficult to reconcile with the earlier data of Paran-

1. Abbreviations used in this paper: $\mathrm{BEC}$, buccal epithelial cells; $\mathrm{CF}$, cystic fibrosis; Gal, galactose; GalNAc, $N$-acetylgalactosamine; Glc, glucose; GlcNAc, $N$-acetylglucosamine; RT, room temperature; SIM, small intestinal mucin; TBM, tracheobronchial mucin; TMU, tetramethylurea. 
chych et al. (14) who showed that pili of PAK strain bound nonspecifically to a whole host of structurally unrelated proteins and glycoproteins. No particular role for carbohydrates as receptor molecules could be demonstrated in a large series of BSA-sugar conjugates. Thus the role of adhesion of $P$. aeruginosa to mucins, the relative affinity of mucins versus other proteins, glycoproteins or glycolipids (including cell surface structures) for these organisms, and the early colonization events in Pseudomonas infection in CF still remain controversial.

This study was undertaken in an effort to discover whether highly purified mucins (from CF sputum and non-CF intestine) exhibited receptor-mediated binding interactions with nonmucoid strains of $P$. aeruginosa. In solid phase assays we measured radioactively labelled bacteria binding to immobilized mucins, and in solution phase assays we measured radiolabelled mucin binding to bacteria. The nature and the extent of mucin-bacterial interactions differed under the two assay conditions used, although in both cases hydrophobic interactions with the pili of $P$. aeruginosa were involved. Neither assay, however, gave any evidence to support the existence of preferential high affinity receptor sites on mucins for the attachment of pili when binding to mucin was compared with binding to other proteins.

Our data do not encourage us, therefore, to construct models of pathogenesis in which the key initial step depends upon a specific receptor site on mucins for adherence of $P$. aeruginosa. Our findings contrast sharply with those reported in the accompanying paper for the interactions of mucins with Pseudomonas cepacia.

\section{Methods}

\section{Bacterial strains and culture conditions}

$P$. aeruginosa (nonmucoid) strains, PAO1, PAK, P1, and HD1 were kindly provided by Dr. W. Paranchych, Department of Microbiology, University of Alberta, Edmonton. Strain K122-4 was supplied by Dr. P. Flemming, Department of Bacteriology, Hospital for Sick Children, Toronto. These strains have been well described in previous publications (15-17). Three other clinical isolates (PANM1, PANM2, and PANM3) were isolated from sputum samples of hospitalized cystic fibrosis patients, and were kindly supplied by Dr. M. Karmali, Division of Microbiology, Hospital for Sick Children, Toronto. All strains were maintained on brain heart infusion agar slants at $-70^{\circ} \mathrm{C}$. In preparation for binding assays, a single colony was inoculated into M9 medium, incubated overnight at $37^{\circ} \mathrm{C}$ in a gyroshaker (at $150 \mathrm{rpm}$; New Brunswick Scientific Co., Inc., Edison, NJ), an aliquot $(1 \mathrm{ml})$ transferred into fresh $\mathrm{M} 9$ medium $(9 \mathrm{ml})$, incubated $3 \mathrm{~h}$, and then supplemented with $0.1 \mathrm{mCi}$ of either $\left[{ }^{3} \mathrm{H}\right]$ sodium acetate (sp act 2-5 Ci/ mmol) or $\left[{ }^{35} \mathrm{~S}\right] \mathrm{L}-$ methionine (sp act $800 \mathrm{Ci} / \mathrm{mmol}$ ). After a further 3-h incubation, the bacteria were harvested by centrifugation $(12,000 \mathrm{~g}$ for 10 min at $4^{\circ} \mathrm{C}$ ), washed three times with PBS pH 7.2, and suspended in the same buffer to give the desired concentration $(0.1$ OD $U$ at $650 \mathrm{~nm}$ was equal to $3 \times 10^{8} \mathrm{CFU} / \mathrm{ml}$ ). Further details of this method are described by McEachran and Irvin (18).

\section{Purification of tracheobronchial (TBM) and small intestinal (SIM) mucins}

TBM was purified from sputum samples of hospitalized CF patients during treatment of lung infection, following the method of Carlstedt et al. (19) with minor modifications. Within $30 \mathrm{~min}$ of expectoration, individual sputum samples were mixed with PBS pH 7.2 containing guanidine hydrochloride, (4 M), PMSF ( $2 \mathrm{mM}), N$-ethylmaleimide ( 5 $\mathrm{mM}), \mathrm{Na}_{2}$ EDTA $(5 \mathrm{mM})$, and $\mathrm{NaN}_{3}(0.02 \% \mathrm{vol} / \mathrm{vol})$. Samples were pooled and centrifuged at $2,000 \mathrm{~g}$ for $15 \mathrm{~min}$ at $4^{\circ} \mathrm{C}$, and the mucous gel pellet redissolved in the same mixture and homogenized in a blender (Waring, New Hartford, CT) for $30 \mathrm{~s}$. After centrifugation at $27,000 \mathrm{~g}$ at $4^{\circ} \mathrm{C}$ for $30 \mathrm{~min}$ to remove cell debris, the supernatant was subjected to two sequential $\mathrm{CsCl}$ density gradient ultracentrifugations in the presence of $4 \mathrm{M}$ and then $0.2 \mathrm{M} \mathrm{GnHCl}$. The final periodic acid/Schiff-positive mucin fractions (20) were pooled (buoyant density $\rho 1.36-1.41 \mathrm{~g} / \mathrm{ml}$ ), dialyzed against distilled $\mathrm{H}_{2} \mathrm{O}$, and stored at $-20^{\circ} \mathrm{C}$ before use.

Human SIM was isolated from small intestinal secretions of a single adult patient who had received an intestinal bypass operation (jejunoileal anastomosis) for the treatment of gross obesity. During a second operation one year later, the distal anastomosis was severed and small intestinal secretions drained through a surgical fistula into an ileostomy bag attached to the abdominal wall. These were collected every $12 \mathrm{~h}$ for $10 \mathrm{~d}$. PMSF (final concentration $2 \mathrm{mM}$ ) was added to each collection bag and the mixture stored at $-20^{\circ} \mathrm{C}$ before our experiments were performed. Since the small bowel remained ligated at the proximal (jejunal) end during the collection, the secretions were uncontaminated by food, bile, pancreatic juice, or gastric contents. Secretions were pooled, dialyzed at $4^{\circ} \mathrm{C}$ against $\mathrm{PBS}$ pH 7.2 containing $\mathrm{PMSF}(2 \mathrm{mM})$, $\mathrm{Na}_{2} \operatorname{EDTA}(10 \mathrm{mM}), \mathrm{NEM}(10 \mathrm{mM})$, and $\mathrm{NaN}_{3}(0.02 \%)$. The retentate was concentrated 10 -fold by a Diaflo apparatus (Amicon, Beverly, MA) (membrane exclusion limit $100 \mathrm{kD}$ ), and then subjected to two sequential $\mathrm{CsCl}$ density gradient ultracentrifugation steps as described previously $(21,22)$.

Analyses of mucins included amino acid and amino sugar assays (Picotag HPLC system; Waters Chromatography Division, Millipore Corp., Milford, MA) (23), carbohydrates (measured by anion exchange chromatography using a BioLC system [Dionex Corp., Sunnyvale, CA] equipped with pulsed amperometric detection) (24), thin layer chromatography for detection of glycolipids (25), and immunoassay for fibronectin (26). Both mucin preparations gave compositions which were almost identical with those published earlier for purified TBM (26) and SIM $(21,22)$ with the exception of sugar composition of SIM. The $\mathrm{N}$-acetylglucosamine (GlcNAc)/GalNAc ratio was slightly higher and sialic acid concentration was somewhat lower than usual. It is possible that some degradation of the mucin occurred prior to purification because the secreted mucin was exposed to other ileal secretions (but no bacteria) for several hours before purification procedures were initiated. Despite these considerations, the mucin was used extensively in this study because it was judged to be reasonably normal and was available in high quantity (unlike TBM) and because it behaved almost identically to TBM with respect to bacterial binding. Both TBM and SIM were free of contaminants such as fibronectin and glycolipids.

\section{Iodination of mucin}

Small intestinal mucin ( $100 \mu \mathrm{g}$ protein) was iodinated using iodobeads (Pierce Chem. Co., Rockford, IL), and passed through Sephadex G-25 (Pharmacia, Uppsala, Sweden) to remove free ${ }^{125} \mathrm{I}$, as described by Chadee et al. (27). Labelled mucin was then mixed with nonradioactive mucin (1:20 vol/vol), and the protein concentration was measured by using the bicinchonic acid assay (28). An aliquot was precipitated for $17 \mathrm{~h}$ at $4^{\circ} \mathrm{C}$ by trichloroacetic acid-phosphotungstic acid (final concentration $5 \%: 1 \% \mathrm{vol} / \mathrm{vol}$ ) in the presence of $0.1 \% \mathrm{BSA}$, and then washed 10 times with PBS pH 7.2. The specific activity of the mucin preparation was $216,542 \mathrm{cpm} / \mu \mathrm{g}$ mucin protein (or $21,654 \mathrm{cpm} / \mu \mathrm{g}$ of total dry wt of mucin).

\section{Isolation of Pseudomonas aeruginosa pili}

Pili were purified from strains PAO1 and PAK by the method of Paranchych et al. (29), in which polyethylene glycol is added to supernatant fractions of bacterial homogenates, the precipitate is then suspended in $10 \%$ ammonium sulfate, and the precipitated pili further purified by $\mathrm{CsCl}$ density gradient ultracentrifugation. The pili gave a single Coomassie blue-positive band at a position of $M_{\mathrm{r}} 15,000$ in SDS-PAGE (12\% gels).

\section{Monoclonal antibody to pilin binding domain}

A monoclonal antibody (PK34C) specific for the PAK pilin-binding domain was prepared as described earlier (4). This antibody is known 
to inhibit the binding of both PAO1 and PAK bacteria and their isolated pili to buccal epithelial cells.

\section{Solid phase assays to measure bacterial binding to immobilized mucin}

Binding of ${ }^{3} \mathrm{H}$-labelled $P$. aeruginosa to mucin-coated microtiter plate wells was performed by the method of Laux et al. (30) with minor modifications as described by Sajjan and Forstner (31). To coat the wells a solution of mucin in distilled water, $(6 \mu \mathrm{g}$ protein $/ 150 \mu \mathrm{l})$ was added and incubated overnight at $4^{\circ} \mathrm{C}$. The wells were washed four times with PBS, leaving $0.46 \mu \mathrm{g}$ of mucin (as protein) bound to the wells (32). The remaining receptor sites were either blocked with $200 \mu \mathrm{l}$ of fatty acid-free 3\% BSA (Sigma Chemical Co., St. Louis, MO) for $1 \mathrm{~h}$ at $37^{\circ} \mathrm{C}$, or, in a separate set of experiments, no blocking agent was used. Excess BSA was removed by four washes with PBS, and then 150 $\mu$ l of ${ }^{3} \mathrm{H}$-labelled $P$. aeruginosa $\left(3 \times 10^{8}\right.$ cells $\left./ \mathrm{ml}\right)$ were added, and left for $1 \mathrm{~h}$ at $37^{\circ} \mathrm{C}$. Unbound bacteria were removed by washing six times with PBS, and the bound radioactivity remaining in the wells was determined by counting individual wells in a beta trac liquid scintillation system (model 6895; Tracor Analytic, Elk Grove Village, IL). As suggested by Laux (30) binding to mucin was considered to be low level (nonspecific) unless it was two to six times greater than binding to BSA. Our data are therefore often expressed as the ratio, $R$, the binding to mucin $\div$ binding to BSA controls. In experiments where no BSA or other blocking agent was used, the binding to mucin was compared with the binding to uncoated wells (background) and to wells coated (but not later blocked) with BSA instead of mucin. Experiments with no blocking agent were performed so as to reproduce the conditions and binding data of Viswanath and Ramphal $(11,12)$ (see Results).

\section{Solution phase assays to measure mucin binding to bacteria}

For these assays much larger amounts of mucin were required, and therefore most experiments were performed using SIM rather than TBM, since the former was available in much greater quantity. ${ }^{125} \mathrm{I}$-labelled SIM (0.5 ml PBS containing 1.4-14.6 $\mu \mathrm{g}$ mucin protein) was mixed with $0.5 \mathrm{ml}$ of $P$. aeruginosa (final concentration $9 \times 10^{8} \mathrm{cell} / \mathrm{ml}$ of PBS) at $\mathrm{pH} 7.2$, and incubated for $1 \mathrm{~h}$ at $37^{\circ} \mathrm{C}$. The mixture was centrifuged for $3 \mathrm{~min}$ at $12,000 \mathrm{~g}$ at room temperature (RT), the bacterial pellet washed 10 times with PBS; and bound mucin counted in a $\gamma$-counter (8000; Beckman Instruments, Inc., Fullerton, CA). Background (nonspecific) binding was calculated by measuring the radioactive mucin bound to Escherichia coli serotype O157:H7 strain CL-49 (nonpiliated form), a strain known not to bind to mucin (31). Other controls consisted of using free ${ }^{125}$ Iodine instead of ${ }^{125} \mathrm{I}$-labelled mucin in incubations with bacteria. In each case, background binding was $<15 \%$ of test samples.

\section{Hapten inhibition studies}

In solid phase assays potential haptens (proteins, carbohydrates) were preincubated for $1 \mathrm{~h}$ at $37^{\circ} \mathrm{C}$ with ${ }^{3} \mathrm{H}$-labelled $P$. aeruginosa $\left(10^{8}\right.$ cells/ $\mathrm{ml}$ ) and the mixture then added to mucin-coated or BSA-coated wells.

In solution phase assays, haptens were also preincubated with $P$. aeruginosa $\left(10^{9}\right.$ cells $\left./ \mathrm{ml}\right)$, and then ${ }^{125} \mathrm{I}$-labelled mucin $(11.68 \mu \mathrm{g}$ mucin protein $/ 0.5 \mathrm{ml}$ PBS) was added to the mixture. The remaining steps of each binding assay were as described above.

In experiments in which purified PAK or PAOl pili were used as haptens, the pili were preincubated $\left(1 \mathrm{~h}, 37^{\circ} \mathrm{C}\right)$ with mucin samples rather than bacteria. For solid phase assays the preincubation was followed by three washes with PBS to remove unbound pili, and the binding assay then carried out as usual. In solution phase assays, the preincubation mixture was added to bacteria and the binding assay continued as usual.

\section{Binding of PAOI and PAK bacteria to buccal epithelial cells $(B E C)$}

The adhesion assay of McEachran and Irvin (18) modified by Doig et al. (3) was used to determine the number of ${ }^{35} \mathrm{~S}$-labelled bacteria bound to $\mathrm{BEC}$ in suspension. When mucins were used as potential inhibiting agents, the labelled bacteria were preincubated $\left(1 \mathrm{~h}\right.$ at $\left.37^{\circ} \mathrm{C}\right)$ with $\mathrm{mu}-$ cin $(50 \mu \mathrm{g} / \mathrm{ml})$, the mixture then added to BEC suspensions, and the binding assay of bacteria to BEC continued in the usual fashion.

\section{Binding of PAOI or PAK pili to mucins}

Microtiter wells were coated with $150 \mu$ l of TBM or SIM containing 5 $\mu \mathrm{g}$ of mucin protein in PBS, incubated overnight at $4^{\circ} \mathrm{C}$, washed twice, blocked with $200 \mu \mathrm{l}$ of $1 \% \mathrm{BSA}$ for $1 \mathrm{~h}$ at $37^{\circ} \mathrm{C}$, and washed again. A $100 \mu \mathrm{l}$ solution of pili (10 to $150 \mu \mathrm{g} / \mathrm{ml}$ in PBS) was added, incubated for $1 \mathrm{~h}$ at RT, the wells washed three times, and bound pili were quantitated by immunoassay as described below. Control (background) binding was measured in wells coated with $1 \%$ BSA alone.

\section{Binding of $P A O 1$ or $P A K$ pili to buccal epithelial cells}

Pili binding to BEC was carried out as described by Doig et al. (4). To assess the effect of mucin on pili adherence to cells, mucins (0-100 $\mu \mathrm{g}$ protein per $1.0 \mathrm{ml} \mathrm{PBS}$ ) were preincubated with an equal volume of pili $(20 \mu \mathrm{g} / \mathrm{ml})$ for $30 \mathrm{~min}$ at RT; to this mixture were added $4 \times 10^{4} \mathrm{BEC}$ in $0.2 \mathrm{ml} \mathrm{PBS}$, and the incubation continued at $37^{\circ} \mathrm{C}$ for $2 \mathrm{~h}$ in a gyroshaker (New Brunswick Scientific Co.). The BECs were collected by centrifugation (12,000 $g$ for $2 \mathrm{~min}$ ), washed three times with PBS pH 7.2 , and then incubated with the monoclonal antibody (PK3B or PK34C for PAK or PAO1 pili, respectively) (4). After $1 \mathrm{~h}$, the unbound antibody was removed by washing, and the remaining bound antibody detected by the use of a goat anti-mouse IgG conjugated to horseradish peroxidase (33). The substrate was $1 \mathrm{mM} \mathrm{2,2'-azino-di-(3-ethylbenz-}$ thiazoline) sulfonic acid in $0.03 \%$ ( $\mathrm{vol} / \mathrm{vol}$ ) hydrogen peroxide in 10 $\mathrm{mM}$ citrate buffer $\mathrm{pH}$ 4.2. Enzymatic activity was determined from the absorbance at $405 \mathrm{~nm}$.

\section{Determination of hydrophobicity}

The phenyl Sepharose (Pharmacia) column method of Rosenberg et al. (34) was used to measure the hydrophobicity of protein and mucin samples. The amount of protein adsorbed to the column was calculated from the difference (OD $280 \mathrm{~nm}$ ) between added and nonadsorbed protein.

\section{Results}

\section{Binding of $P$. aeruginosa to mucin in solid phase binding} assays

(a) With the use of a blocking agent. In the first set of experiments, eight strains of $P$. aeruginos $a$ were tested at three different concentrations for their capacity to bind to mucin-coated or BSA-coated wells. The binding parameter, $R$, (the ratio of mucin binding $\div$ BSA binding) is given in Table I. Although all of the strains bound to both normal human SIM and CF TBM, the $R$ values were similar for both mucins. $R$ values also rarely exceeded 1.0, except for one concentration of PAO1 $(R$ $=2.02$ ). There was therefore little evidence to suggest a preference in the binding of Pseudomonas strains to mucin versus albumin. As a substitute for BSA as a blocking agent and as a coating agent, casein and gelatin were used but neither gave more favourable mucin-binding data (not shown). Several other modifications (not shown) in subsequent binding assays of strains PAO1 and PAK were similarly ineffective, including variations in bacterial-mucin incubation times $(15 \mathrm{~min}-3 \mathrm{~h})$, temperatures $\left(20^{\circ}-37^{\circ} \mathrm{C}\right), \mathrm{pH}$ values $(5.8-8.0)$, or the addition of divalent cations (5-10 $\mathrm{mM} \mathrm{CaCl} 2$ or $\mathrm{MgCl}_{2}$ ). Substitutions of different BSA preparations (Cohn fraction V, globulin-free BSA) for the usual fatty acid-free BSA preparation (Sigma Chemical Co.) which was used in the assays, were also not helpful. Another modification consisted of growing bacteria (strains PAOl and PAK) in different media before their $1 \mathrm{~h}$ 
Table I. Binding of Nonmucoid P. aeruginosa to Immobilized Mucin

\begin{tabular}{|c|c|c|c|}
\hline \multirow[b]{2}{*}{ Bacterial strain } & \multirow[b]{2}{*}{ Bacteria added } & \multicolumn{2}{|c|}{ Binding parameter $(R)$} \\
\hline & & TBM & SIM \\
\hline & $\mathrm{CFU} / \mathrm{ml}$ & & \\
\hline PAO1 & $7.8 \times 10^{7}-2.9 \times 10^{9}$ & $0.88-1.92$ & $0.69-2.02$ \\
\hline PAK & $5.1 \times 10^{7}-3.9 \times 10^{9}$ & $0.73-0.97$ & $0.77-1.00$ \\
\hline K122-4 & $9.6 \times 10^{8}-3.5 \times 10^{9}$ & $0.87-1.09$ & $0.81-0.84$ \\
\hline HD1 & $8.1 \times 10^{8}-3.1 \times 10^{9}$ & $0.90-0.96$ & $0.74-1.34$ \\
\hline P1 & $1.6 \times 10^{7}-2.7 \times 10^{9}$ & $0.37-0.46$ & $0.39-0.56$ \\
\hline PANM1 & $6.0 \times 10^{7}-3.5 \times 10^{9}$ & $0.56-0.92$ & $0.57-0.80$ \\
\hline PANM2 & $8.7 \times 10^{7}-3.3 \times 10^{9}$ & $0.90-1.05$ & $0.75-0.79$ \\
\hline PANM3 & $3.3 \times 10^{7}-3.2 \times 10^{9}$ & $0.41-0.75$ & $0.47-0.89$ \\
\hline
\end{tabular}

Microtiter wells were coated with $5 \mu \mathrm{g}$ of TBM, SIM, or BSA, unoccupied sites were blocked with $3 \%$ BSA, and the binding of ${ }^{3} \mathrm{H}$-labelled bacteria ( 3 concentrations) was measured as described in Methods. $\mathbf{R}$ is the ratio of mucin binding $\div$ BSA binding. Values represent the range of bacterial concentration, and $R$ values obtained, from averaging three experiments per each concentration employed.

incubation with mucin. Instead of the standard M9 medium, bacteria were grown in trypticase soy broth or brain heart infusion broth (Difco Laboratories, Inc., Detroit, MI) or M9 synthetic medium (35) supplemented with SIM or glucose or BSA. In no case did these modifications increase the value of the binding parameter, $R$, for mucin.

(b) Without the use of a blocking agent. Viswanath and Ramphal $(11,12)$ and Ramphal et al. $(13,36)$ reported the binding of $P$. aeruginosa (a PAK strain designated R1) to respiratory mucin using a microtiter well solid phase assay in which no blocking agent was used. Nonspecific binding was calculated from the number of bacteria bound to uncoated wells or siliconized wells. We therefore reproduced these conditions in experiments measuring the binding of four strains of $P$. aeruginosa (PAO1, P1, HP, $\mathrm{PANM}_{3}$ ) to both tracheobronchial and small intestinal mucin and compared bacterial binding to mucin with binding to BSA. The data from three experiments (shown in Fig. 1 for strain PAO1) were virtually identical for all four strains. That is, at high bacterial concentrations $(>20$ $\times 10^{8} \mathrm{CFU} / \mathrm{ml}$ ) curves for bacterial binding to the two mucins, to BSA, and to uncoated wells did not saturate and were virtually indistinguishable. However, at low bacterial concentrations (2-6 $\left.\times 10^{8} \mathrm{CFU} / \mathrm{ml}\right)$ the two mucins (equally) bound about two times more bacteria than either BSA or uncoated wells. The differences between binding to mucins versus uncoated wells were almost the same as those reported by Viswanath and Ramphal et al. (11). In the hopes that these assay conditions might permit further characterization of binding specificity of mucin versus BSA, we carried out inhibition experiments through this "window", namely, in the presence of a low concentration $\left(2-4 \times 10^{8} \mathrm{CFU} / \mathrm{ml}\right)$ of added bacteria.

(c) Hapten inhibition in solid phase assays (without a blocking agent). As shown in Table II the binding of $P$. aeruginosa, strain PAO1, to uncoated wells or to wells coated with BSA, SIM, or TBM, was not inhibited by any of the carbohydrates tested. In most cases (including uncoated wells) there was actually an enhancement of bacterial binding, presumably due to nonspecific and variable bacterial aggregation by sugars. The

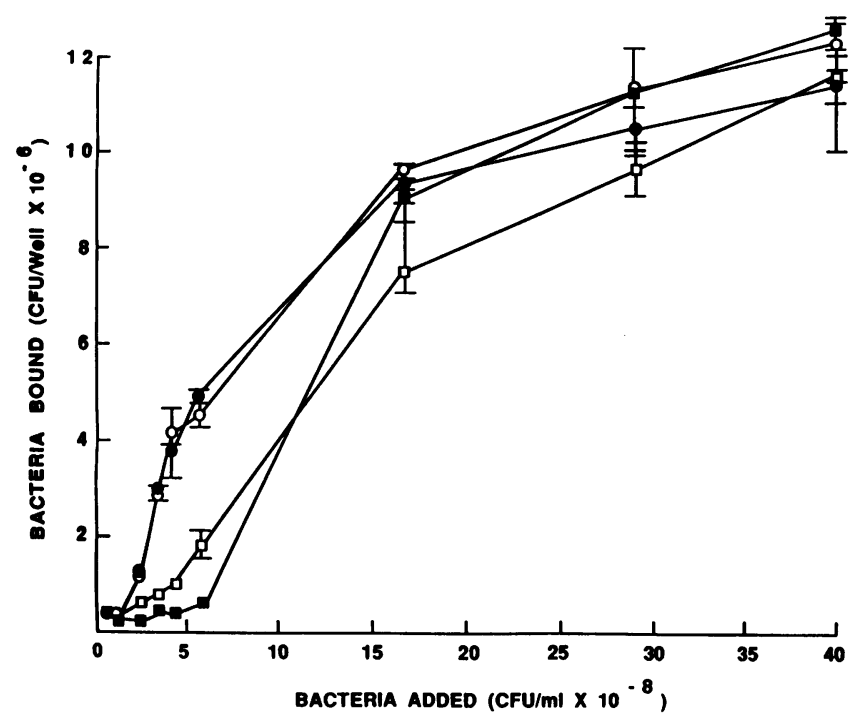

Figure 1. Binding of $P$. aeruginosa (PAO1) to mucins, BSA, and uncoated wells in the absence of a blocking agent. Experimental conditions were similar to those given for Table I, except that coated wells were not blocked before the addition of ${ }^{3} \mathrm{H}$-bacteria. Values represent the average of triplicate experiments and bars represent the total range of values obtained. O, TBM; •, SIM; $\square$, BSA; $₫$, uncoated wells.

mechanism of enhancement was not further explored since it was clear from these experiments that specific hapten inhibition had not been demonstrated. There was, in particular, no evidence to support the notion that a mucin receptor for $P$. aeruginosa relied upon sialic acid, $N$-acetylglucosamine, or the

Table II. Effect of Carbohydrates on the Binding of PAOI to Mucins and BSA

\begin{tabular}{|c|c|c|c|c|}
\hline \multirow[b]{2}{*}{ Carbohydrate } & \multicolumn{4}{|c|}{ Percent binding to } \\
\hline & Uncoated wells & SIM & TBM & BSA \\
\hline No addition & 100 & 100 & 100 & 100 \\
\hline L-fucose & 1085 & 95 & 117 & 140 \\
\hline D-fucose & 147 & 983 & 711 & 969 \\
\hline L-arabinose & 384 & 111 & 134 & 140 \\
\hline D-mannose & 160 & 285 & 239 & 312 \\
\hline D-glucose & 146 & 179 & 190 & 918 \\
\hline D-galactose & 276 & 120 & 143 & 162 \\
\hline$N$-acetyl D-glucosamine & 837 & 100 & 122 & 104 \\
\hline$N$-acetyl D-galactosamine & 188 & 285 & 263 & 324 \\
\hline$N$-acetyl neuraminic acid & 110 & 183 & 118 & 216 \\
\hline${ }^{*} \mathrm{Gal} \beta 1,3$ GlcNAC & 476 & 160 & 130 & 179 \\
\hline${ }^{*} \mathrm{Gal} \beta$ 1,4 GlcNAc & 150 & 134 & 133 & 145 \\
\hline${ }^{*} \mathrm{Gal} \beta$ 1,6 GlcNAc & 102 & 306 & 807 & 479 \\
\hline${ }^{*} \mathrm{Gal} \beta \quad 1,3 \mathrm{Gal} \beta \quad 1,3 \mathrm{GlcNAc}$ & 88 & 176 & 182 & 259 \\
\hline
\end{tabular}

${ }^{3} \mathrm{H}$-bacteria in PBS $\left(2.1 \times 10^{8} \mathrm{CFU} / \mathrm{ml}\right)$ were preincubated with 20 $\mathrm{mM}$ solutions of carbohydrate $(10 \mathrm{mM}$ for those marked with an asterisk) for $1 \mathrm{~h}$ at $37^{\circ} \mathrm{C}$, and samples ( $150 \mu \mathrm{l}$ each) then added to triplicate microtiter plate wells previously coated with SIM, TBM, or BSA ( $5 \mu \mathrm{g}$ protein) or to uncoated wells. No blocking agent was used in the binding assay protocol. $100 \%$ binding was equivalent to 2,193 , $1,815,1,673$, and $200 \mathrm{dpm}$ for SIM, TBM, BSA, and uncoated wells, respectively. Each value is the average of triplicate experiments. 
sequence $\operatorname{Gal} \beta 1,4 \mathrm{GlcNAc}$ as has been suggested by Viswanath and Ramphal (12) and Ramphal et al. (13) using a similar binding assay.

Several proteins and glycoproteins were also tested as potential inhibitors of bacterial binding to TBM and BSA. Fig. 2, $A$ and $B$, shows that many structurally unrelated compounds caused inhibition, but they produced almost identical concentration-dependent inhibition profiles for both TBM and BSA. Some proteins actually caused enhanced binding (pepsin and cytochrome $c$ ) and BSA gave a biphasic response. These results are difficult to interpret, but are reminiscent of the earlier data of Paranchych et al. (14) who noted the binding of PAK pili to a wide variety of proteins immobilized in microtiter wells. Our data probably reflect a combination of protein-induced bacterial aggregation, nonspecific inhibition and/or variable adhesion of protein-bacterial complexes to "free" (nonblocked) sites in the microtiter wells. Importantly however, we were not able to discern a difference in the action of any of these proteins on BSA binding versus mucin binding of $P$. aeruginosa.

(d) Effect of tetramethylurea in solid phase assays. Since none of the evidence supported the existence of specific receptor sites on mucin with higher affinity than those on BSA, we tested the possibility that nonspecific hydrophobic interactions might mediate the observed binding to both BSA and mucin. Tetramethylurea (TMU), a strong disrupting agent of hydrophobic interactions (37), was preincubated with PAO1 bacteria and the mixture then added to mucin-coated or BSA-coated wells. Although bacterial viability was not affected by TMU (not shown), binding to both mucin and BSA were virtually abolished by the presence of a low concentration $(0.05 \mathrm{M})$ of TMU (Table III, column A). This suggests that the binding of bacteria to both mucins and BSA was mediated by weak hydrophobic interactions.

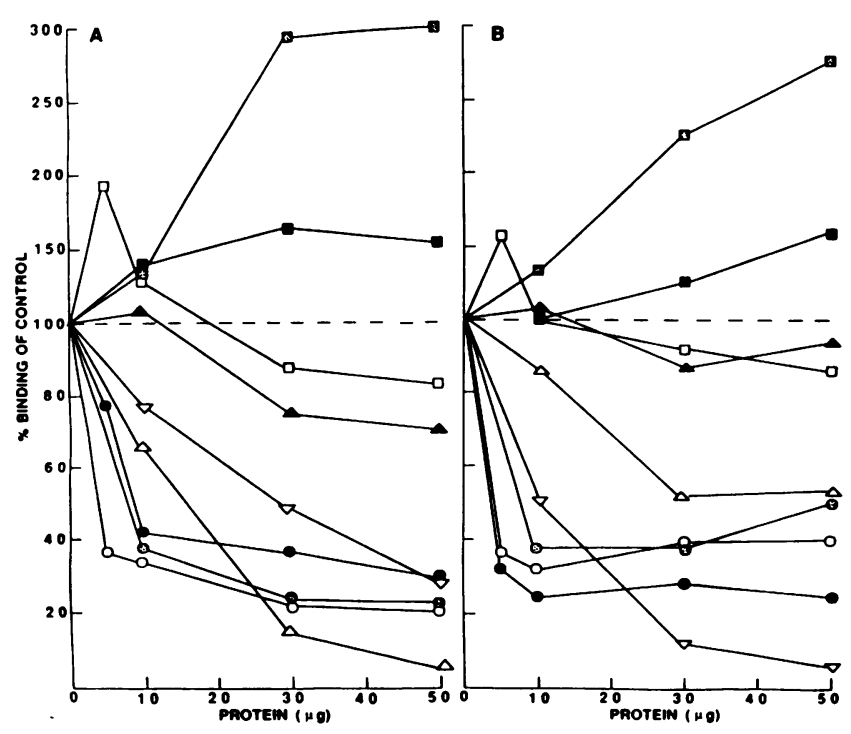

Figure 2. Effect of mucin and nonmucin proteins on the binding of $P$. aeruginosa to mucin (TBM) $(A)$ and BSA $(B)$. Several proteins and glycoproteins, including mucins $(0-50 \mu \mathrm{g})$ were separately preincubated for $1 \mathrm{~h}$ at $37^{\circ} \mathrm{C}$ with PAO1 $\left(2.2-3.4 \times 10^{8} \mathrm{CFU} / \mathrm{ml}\right)$, and the mixture then added into $(A)$ mucin or $(B)$ BSA-coated wells $(6.0 \mu \mathrm{g}$ / well). Each value represents the average of triplicate experiments. $\bullet$, SIM; O, TBM; $\square$, BSA; $₫$, cytochrome $c$; $\Delta$, phosphorylase $b ; \nabla$, fumarase; $\Delta$, fetuin; $\square$, pepsin; $O$, aldolase. All proteins or glycoproteins (except mucins) were obtained from Sigma Chemical Co.
Table III. Effect of Tetramethylurea on PAOI Bacterial Binding

\begin{tabular}{|c|c|c|c|}
\hline \multirow{3}{*}{$\frac{\text { Tetramethylurea }}{M}$} & \multicolumn{3}{|c|}{ Inhibition (\%) of binding } \\
\hline & \multicolumn{2}{|c|}{ A } & \multirow{2}{*}{$\frac{\text { B }}{\text { SIM }}$} \\
\hline & BSA & SIM & \\
\hline 0.00 & 0 & 0 & 0 \\
\hline 0.01 & $45(32-52)$ & $95(41-54)$ & 0 \\
\hline 0.05 & $93(91-96)$ & $91(88-91)$ & $32(28-39)$ \\
\hline 0.10 & $97(96-98)$ & $93(93-93)$ & $33(27-39)$ \\
\hline 0.50 & NT & NT & $36(33-38)$ \\
\hline 1.0 & NT & NT & $37(35-40)$ \\
\hline
\end{tabular}

$A$ and $B$ refer to solid and solution phase binding assay data, respectively. ${ }^{3} \mathrm{H}$-bacteria $\left(4.5 \times 10^{7}\right.$ cells $)$ suspended in PBS containing TMU (0-0.01 M) were incubated in mucin- or BSA-coated wells in $A$ assays. In $B$ assays, nonradioactive bacteria $\left(9 \times 10^{8} \mathrm{CFU} / \mathrm{ml}\right)$ suspended in PBS containing TMU (0 to $1 \mathrm{M})$ were incubated with ${ }^{125} \mathrm{I}$-mucin $\left(3.1 \times 10^{6} \mathrm{cpm}\right)$. Subsequent adherence of mucin and bacteria was quantitated as described in Methods. Binding at $0 \%$ inhibition was 3,320 and 3,510 for BSA and SIM, respectively, in A, and $86,283 \mathrm{cpm}$ in B. NT means not tested. Each value is the average of triplicate experiments, with the total range of data shown in brackets.

\section{Binding of $P$. aeruginosa to mucin in solution phase binding assays}

To eliminate the need for a blocking agent, and in the hope of causing greater exposure of potential receptor sites on mucin, we developed a solution phase binding assay. ${ }^{125} \mathrm{I}$-labelled mucin at varying concentrations was incubated with PAO1 bacteria $\left(1 \times 10^{9}\right.$ cells $\left./ \mathrm{ml}\right)$ and mucin binding quantitated and plotted as shown in Fig. 3. Binding was saturable with increasing mucin concentration (Fig. $3 a$ ) and inhibited by the addition of nonradioactive mucins (SIM, TBM). Thus mucin binding was an equilibrium process and saturation indicated the involvement of a finite number of bacterial attachment sites. A Langmuir adsorption isotherm (Fig. $3 b$ ) gave a linear plot (correlation coefficient, $r=0.946$ ) suggestive of a single type of noninteracting bacterial adhesion sites. The association constant, $K$, was $0.473 \pm 0.071 \mathrm{ml} / \mu \mathrm{g}$ mucin and the total number of available sites for mucin $(N)$ was $3.902 \pm 0.353 \times 10^{-10} \mu \mathrm{g} /$ cell.

By converting the $N$ value to units of bacterial cells bound per micrograms of mucin, a value of $6.41 \times 10^{10}$ bacterial cells would be expected to be able to bind at saturation to $5 \mu \mathrm{g}$ (as protein) of mucin. This represents much more binding (three orders of magnitude) than was ever obtained in solid phase assays. (Fig. 1 shows that the maximum binding was $1.2 \times 10^{7}$ CFU/well). Thus mucin in solution appeared to be much more effective than immobilized mucin in adhering to bacteria.

(a) Effect of tetramethylurea in solution phase assays. The nature of $P$. aeruginosa-mucin interactions also differed from that observed in solid phase assays, since TMU was only able to diminish binding by $37 \%$ (Table III, column B) even at high concentrations $(1 \mathrm{M})$. This suggests that in addition to nonspecific hydrophobic interactions, other bonding forces were responsible for mucin adherence.

(b) Hapten inhibition studies in solution phase assays. The same carbohydrate and protein components that had been tested earlier in solid phase assays were also explored in solution phase binding assays. Bacteria (PAO1) were preincubated with each potential hapten for $1 \mathrm{~h}$ at $37^{\circ} \mathrm{C}$ and the mixture then 

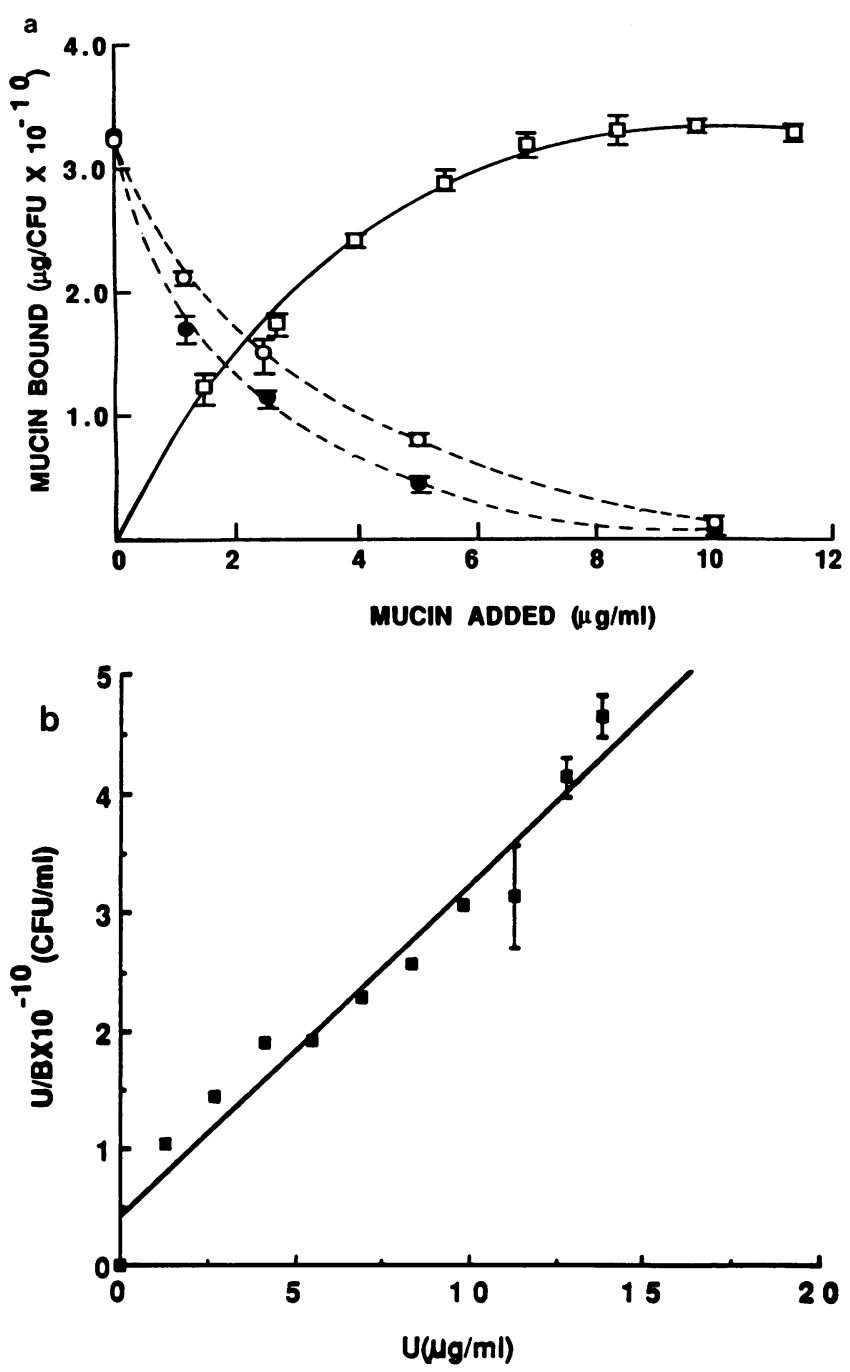

Figure 3. (a) Binding of ${ }^{125} \mathrm{I}$-labelled mucin to PAO1. ${ }^{125} \mathrm{I}$-labelled human small intestinal mucin (216542 cpm per $\mu \mathrm{g}$ protein) was incubated with PAO1 $\left(2.5 \times 10^{9} \mathrm{CFU} / \mathrm{ml}\right)$ in PBS pH 7.2 for $1 \mathrm{~h}$ at $37^{\circ} \mathrm{C}$, the mixture centrifuged, and the pellet washed 10 times with PBS. Control assays were performed with nonmucin binding $E$. coli O157:H7 strain CL-49 (nonpilated) bacteria or/and free Na- ${ }^{125} \mathrm{I}$. Values presented $(-\square-)$ have been corrected for nonspecific binding and represent the mean and total range (bars) of three to five experiments per mucin concentration. Dashed lines represent experiments in which nonradioactive SIM (- - -) or TBM (- - ) were mixed with ${ }^{125}$ I-SIM before the addition of bacteria. (b) Langmuir adsorption isotherm of ${ }^{125} \mathrm{I}$-SIM binding to PAO1. The data were derived from the data of Fig. $3 a(-\square-)$ and gave a straight line with a correlation coefficient, $r=0.946, n$ (saturation number of sites) of $3.902 \pm 0.353$ $\mu \mathrm{g} \times 10^{-10} \mathrm{mucin} / \mathrm{bacterium}$, and the association constant $K$ $=0.473 \pm 0.071 \mathrm{ml} / \mu \mathrm{g}$ mucin $( \pm \mathrm{SD}) . \mathrm{U}$, unbound mucin; $\mathrm{B}$, bound mucin $(\mu \mathrm{g} / \mathrm{CFU})$.

added to ${ }^{125} \mathrm{I}$-mucin in solution. Carbohydrates had no effect on binding either to enhance or to inhibit it (not shown), whereas all of the proteins competed with ${ }^{125} \mathrm{I}$-mucin binding (Fig. 4). The most potent inhibitors were BSA and pepsin, which caused $\sim 80 \%$ inhibition when used in the same concentration $(\sim 10-12 \mu \mathrm{g} / \mathrm{ml})$ as the standard ${ }^{125}$ I-labelled mucin $(11.6 \mu \mathrm{g} / \mathrm{ml})$. Since BSA is free of carbohydrate, it is unlikely that mucin carbohydrate structures mediate bacterial binding. Several other proteins were also very effective inhibitors, but because they do not share any known common structural features, the basis for inhibition was not obvious. A comparison of the hydrophobicity of each protein was carried out to discover whether binding to PAOl correlated with the overall hydrophobic properties of the proteins. In decreasing rank, the percentage that bound to phenyl Sepharose was as follows: aldolase $(99.5 \%)$, fetuin $(97.7 \%)$, fumarase $(77.0 \%)$, phosphorylase $b(74.0 \%)$, BSA $(62.3 \%)$, pepsin $(42.1 \%)$, SIM (38.1\%), TBM (23.7\%) and cytochrome $c(15.8 \%)$. Clearly no relationship was apparent between the overall hydrophobicity and potency of each protein as an inhibitor of mucin binding to bacteria.

Taken altogether, these results suggested that $P$. aeruginos $a$ do not bind to mucin by a specific receptor-mediated phenomena, hence no further studies were carried out to find a specific receptor on the mucin molecule.

\section{Bacterial adhesins for mucin}

Since pili on $P$. aeruginosa mediate the attachment of bacteria to epithelial cells (1-3), we sought evidence for the involvement of the same structures in adherence to mucin and BSA. Both solid and solution phase assays were used, with the use of purified PAO1 and PAK pili as potential hapten inhibitors. In the first set of experiments (solid phase assays without a blocking agent) purified pili were preincubated with mucin or BSA $\left(1 \mathrm{~h}\right.$ at $\left.37^{\circ} \mathrm{C}\right)$ in microtiter wells, nonbound pili were removed by washing, and ${ }^{3} \mathrm{H}$-labelled bacteria then added and binding measured. In a second set of experiments (solution phase assays) pili were preincubated with ${ }^{125} \mathrm{I}$-mucin in solution ( $1 \mathrm{~h}$ at $37^{\circ} \mathrm{C}$ ) before the addition of nonradioactive bacteria. Fig. 5, $a$ and $b$, shows that purified pili inhibited mucin-bacterial (and BSA-bacterial) interactions in both cases, giving the highest percentage inhibition (80\% with PAO1 pili) in solution phase assays (Fig. $5 b$ ). Saturation was not achieved. In solid phase assays (Fig. $5 a$ ) no more than $60 \%$ inhibition of binding could be achieved even at saturation.

Direct binding studies of pili to immobilized mucin and BSA (in microtiter wells) were also performed. Table IV shows the binding parameters for [mucin] $\div$ [BSA] binding over a range of PAK and PAO1 pili concentrations. Both pili bound to both mucins, although somewhat greater binding was exhibited by PAO1 pili in each case. However, the $R$ values were never greater than 2.4 , indicating only a slight (probably negligible) preference of pili for mucins versus BSA.

These experiments suggested that pili play a role in mediating the adherence of $P$. aeruginos $a$ to both mucin and BSA. Pili are likely to be the major attachment sites for mucins in solution phase binding assays. In solid phase assays inhibition by pili saturated at $\sim 60 \%$, suggesting that some other binding phenomenon (probably nonspecific hydrophobic interactions) also contributed substantially to the adherence process.

\section{Effect of mucin on P. aeruginosa binding to buccal epithelial cells}

Ramphal and Pyle (38) have reported that respiratory mucin can prevent the adherence of $P$. aeruginosa to respiratory cells, and have suggested that this action may have important consequences for lung colonization in patients with cystic fibrosis. However, in studies of the binding of whole bacteria (Table $\mathrm{V}$ A) or bacterial pili (Table V B) to BECs, we were unable to demonstrate any interference in binding to BECs by either SIM or TBM even when the two mucins were used at concentrations as high as 50 and $100 \mu \mathrm{g}$ (as protein) per $\mathrm{ml}$. These findings indicate that the pili binding domain for BECs differs from 


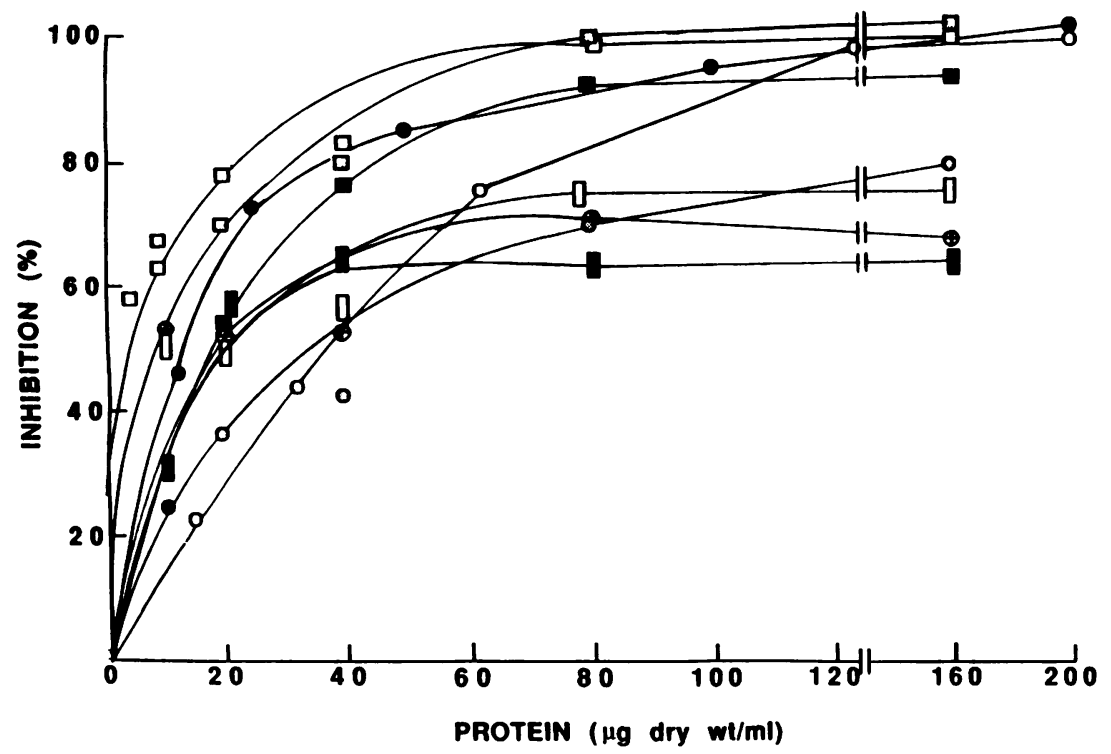

Figure 4. Effect of proteins on the binding of ${ }^{125} \mathrm{I}$ mucin to PAO1. Proteins (0-200 $\mu \mathrm{g}$ dry wt $/ \mathrm{ml})$ were preincubated with PAO1 $\left(2 \times 10^{9}\right.$ cells $\left./ \mathrm{ml}\right)$ for $1 \mathrm{~h}$ at $37^{\circ} \mathrm{C}$ and then mixed with ${ }^{125} \mathrm{I}$-mucin $(11.6 \mu \mathrm{g}$ protein $/ \mathrm{ml})$ and the assay continued as described in Methods. Each value represents the average of triplicate experiments $\circ$, TBM; $\bullet$, SIM; 0 , phosphorylase $b$; $\square$, BSA; $₫$, fetuin; $\square$, pepsin; $\oplus$, cytochrome $c$; $\square$, aldolase; $\square$, fumarase. the domain involved in bacterial binding to mucin. This interpretation was supported in separate experiments (not shown) in which $0.3-3 \mathrm{mg} / \mathrm{ml}$ of a monoclonal antibody (Fab fragments of PK34C) specific for the pilus binding domain for BECs (4), were unable to compete with the binding of ${ }^{125} \mathrm{I}-\mathrm{mu}$ cin to PAO1 bacteria in solution phase assays.

By extrapolation, therefore, we would not expect mucins in vivo to prevent $P$. aeruginosa from binding to respiratory epithelial cells.

\section{Discussion}

Although mucins have been suggested as the preferential primary site for adherence and colonization of $P$. aeruginosa in the lungs of patients with cystic fibrosis (39), the present experiments do not support the existence of specific mucin receptors for this organism. Our data also do not support the notion that sialic acid and amino sugars are important components of mucin receptors, nor that receptors on mucins are the same as those on cell surfaces. In solid phase binding assays we observed that as the concentration of $P$. aeruginosa increased, the bacteria bound equally to small intestinal mucin, tracheobronchial mucin (from CF patients), BSA, several other proteins, and even to uncoated wells. True saturation of binding was not achieved for any of these substrates. Since bacterial binding to mucins and BSA was abolished by a low concentration $(0.05$ M) of tetramethylurea, binding can probably be attributed to non-specific hydrophobic interactions. This interpretation is consistent with the work of Garber et al. (40) who demonstrated the importance of hydrophobic bond-breaking agents in the inhibition of haemagglutination by several strains of $P$. aeruginosa. In sharp contrast to $P$. aeruginosa, many clinical isolates of $P$. cepacia which are described in the next paper, showed significant binding to mucins, and these interactions were not affected by high concentrations of tetramethylurea.

No specific binding role for mucin mono- or oligosaccharides in $P$. aeruginosa adherence was suggested by the results of hapten inhibition experiments, even for the sequence $\mathrm{Gal} \beta 1,4$ GlcNAc which has been reported (13) to inhibit the binding of piliated $P$. aeruginosa to whole respiratory mucin. In view of the recent demonstrations by Krivan et al. (5), Baker et al. (6) and Panjwani et al. (41), that certain glycosphingolipids (partic- ularly those containing the sequence GalNAc $\beta$ 1,4 Gal) have specific receptor activity for nonmucoid $P$. aeruginosa, it is possible that the mucin binding described by Ramphal et al. (13) was due to contaminating glycolipids in the 'whole' (i.e., impure) mucins employed. Indeed, these investigators have themselves suggested recently that cellular glycolipids that are shed into airway mucus secretions, may contribute significantly to bacterial binding (36).

Solution phase assays to examine mucin binding to Pseudomonas aeruginosa were useful because they eliminated both the need for a blocking agent and the anomalies encountered in hapten inhibition studies performed in solid phase assays in the absence of a blocking agent. The solution phase assays revealed that mucin bound to a finite set of bacterial receptors, but once again no evidence for a specific mucin ligand was obtained. That is, carbohydrates did not inhibit binding and many structurally dissimilar proteins (including BSA) were able to compete effectively with mucin. These findings are qualitatively similar to those reported by Paranchych et al. (14) in which pure PAK pili were shown to bind in varying degrees to a host of different proteins, but not to 38 different BSA-carbohydrate conjugates.

An interesting feature of the solution phase assays in this study was that the extent of mucin-bacterial adherence was much greater than that obtained in solid phase assays, and the interaction was not due entirely to weak nonspecific hydrophobic interactions. The potency of inhibitory proteins did not correlate with their net hydrophobicity. We assume that mucin in solution is conformationally more flexible than it is when immobilized in microtiter wells, and thus coats bacteria more easily or makes contact with bacterial binding sites more readily.

In keeping with the findings of Ramphal et al. (42) our studies suggest strongly that pili on $P$. aeruginosa are important, although perhaps not the sole agent responsible for bacterial interactions with mucins. Pili were able to cause partial inhibition of binding in solid, and especially in solution, phase assays, and direct pili-binding experiments confirmed that PAK and PAO1 pili could bind to mucin. Importantly however, we showed that pili bind almost as well to BSA as to mucin, thereby confirming that no strong preference for mucin exists. 

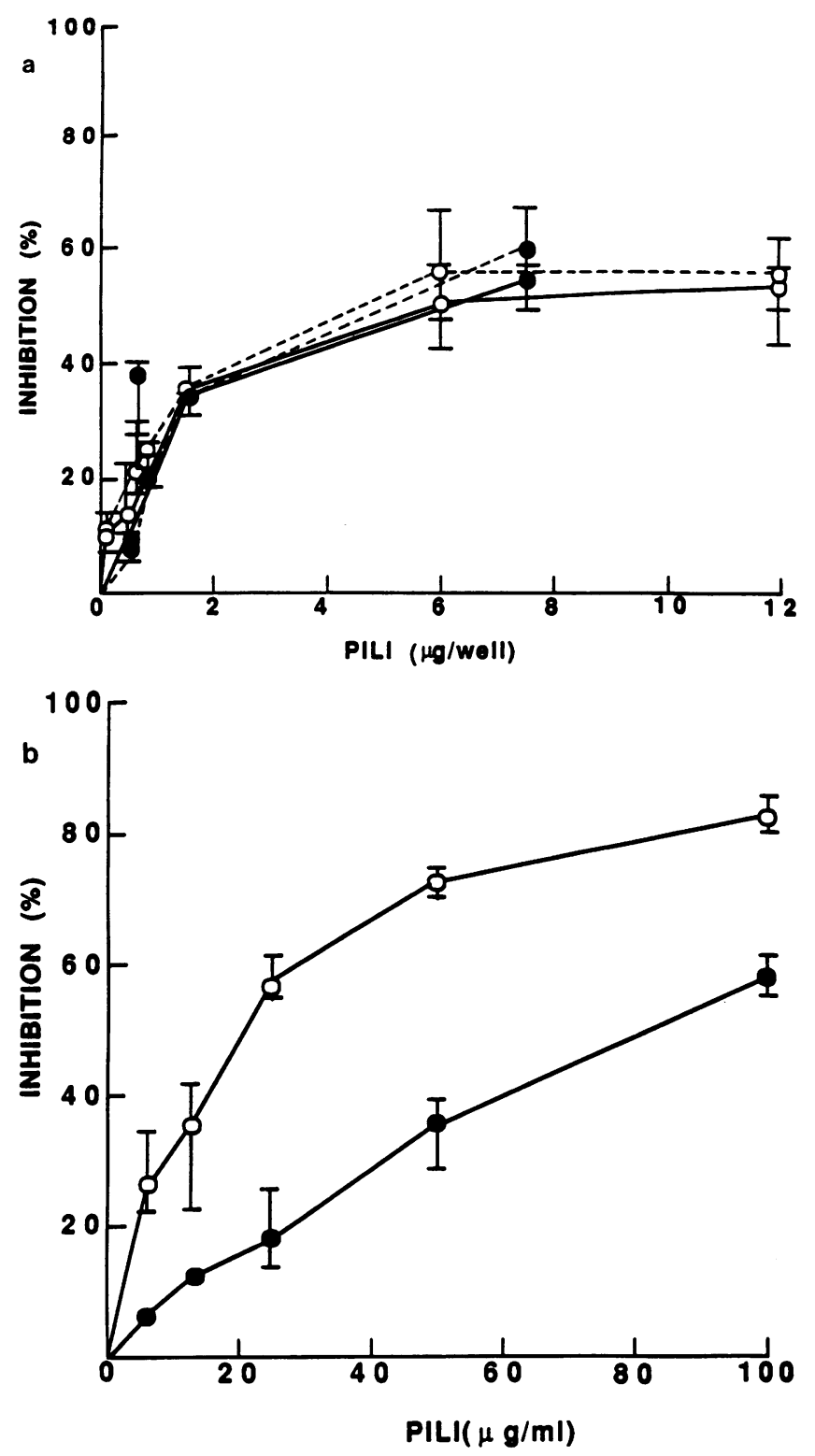

Figure 5. Effect of PAK or PAO1 pili on bacterial-mucin interactions. (a) PAK or PAO1 pili $(0-80 \mu \mathrm{g} / \mathrm{ml})$ were preincubated for $1 \mathrm{~h}$ in mucin- or BSA-coated wells and the unbound pili were removed by washing with PBS. ${ }^{3} \mathrm{H}$-bacteria $\left(2.5 \times 10^{8} \mathrm{cells} / \mathrm{ml}\right)$ were then added and the assay was continued as described under Table I. $\circ$, PAOI pili; •, PAK pili; ——, mucin; - - -, BSA. (b) PAO1 (o) or PAK (๑) pili $(0-100 \mu \mathrm{g} / \mathrm{ml})$ were preincubated with ${ }^{125} \mathrm{I}$-labelled mucin $(11.6 \mu \mathrm{g}$ protein $/ \mathrm{ml})$ for $1 \mathrm{~h}$ at $37^{\circ} \mathrm{C}$, unlabelled bacteria $\left(2.5 \times 10^{9}\right.$ cells $/ \mathrm{ml}$ ) were added and the assay was continued as described for solution phase assays.

Earlier experiments by Ramphal and Pyle (38) demonstrated that crude mucins prevented the adherence of mucoid and nonmucoid $P$. aeruginosa to injured tracheal epithelium of mice. As a result, Ramphal and Vishwanath (39) have speculated that respiratory cells of CF patients do not initially become colonized by $P$. aeruginosa; rather, it is mucin that is the major initial attractant. Our own experiments in which we measured the binding of $P$. aeruginosa and isolated pili to BECs, used highly purified respiratory and intestinal mucins as potential inhibitors. We did not observe a decrease in bacterial binding to BECs even with extraordinarily high concentrations of mucins ( 50 and $100 \mu \mathrm{g}$ [as protein] per $\mathrm{ml}$ ). We assume that
Table IV. Determination of PAO and PAK Pili Binding to Immobilized Mucins

\begin{tabular}{rrrrrr}
\hline & \multicolumn{2}{c}{ TBM } & & \multicolumn{2}{c}{ SIM } \\
\cline { 2 - 3 } \cline { 5 - 6 } Pili & PAO1 pili & PAK pili & & PAO1 pili & PAK pili \\
\hline$\mu g / m l$ & & & & \\
& & & & \\
10 & $2.40 \pm 0.14$ & $1.18 \pm 0.05$ & & $2.33 \pm 0.14$ & $0.87 \pm 0.03$ \\
50 & $1.83 \pm 0.12$ & $1.11 \pm 0.05$ & & $1.62 \pm 0.02$ & $0.77 \pm 0.05$ \\
100 & $1.70 \pm 0.03$ & $1.13 \pm 0.06$ & & $1.47 \pm 0.06$ & $0.76 \pm 0.08$ \\
150 & $1.54 \pm 0.05$ & $1.22 \pm 0.05$ & & $1.32 \pm 0.06$ & $0.81 \pm 0.08$ \\
& & & & & \\
\hline
\end{tabular}

Wells were coated with $5 \mu \mathrm{g}$ mucin (as protein) in PBS and then the unoccupied sites were blocked with $1 \%$ BSA. Values given are mean \pm SD of six experiments and represent the ratio of pili bound to mucin divided by pili bound to BSA alone.

the difference between our results and those of Ramphal and Vishwanath (39) is due to a greater purity of our mucin preparations.

The $\mathrm{COOH}$-terminal domains of PAK and PAOI pilin proteins are known to be of prime importance in attaching these strains of $P$. aeruginosa to BECs, and adherence can be blocked by the MAb PK34C (4) which is specific for the PAK pili binding domain. However, bacterial binding to mucin or BSA in the present solid phase experiments was not altered by preincubation of the bacteria with PK34C. Therefore we conclude that other domains of the pilin protein must be required for bacterial attachment to mucin and BSA. In view of the effects of TMU to abolish binding, the highly hydrophobic $\mathrm{NH}_{2}$-terminal region, which is conserved amongst all $P$. aeruginosa strains (43), may play a role in nonspecific attachment of pili to a host of unrelated substrates.

Implications for the development of lung infections in cystic fibrosis. With increasing age of patients with cystic fibrosis, $P$. aeruginosa predominate in the lung and are associated with progressive chronic respiratory infection. However, the bio-

Table V. Effect of mucins on the binding of P. aeruginosa and purified pili to buccal epithelial cells

\begin{tabular}{|c|c|c|c|c|}
\hline & \multicolumn{4}{|c|}{ Percent binding of control } \\
\hline & \multicolumn{2}{|c|}{ TBM } & \multicolumn{2}{|c|}{ SIM } \\
\hline & \multicolumn{2}{|c|}{$50 \mu g$} & \multicolumn{2}{|c|}{$50 \mu g$} \\
\hline \multicolumn{5}{|c|}{ A Bacteria } \\
\hline PAK & \multicolumn{2}{|c|}{$98.0 \pm 5.4$} & \multicolumn{2}{|c|}{$101.6 \pm 3.7$} \\
\hline \multirow[t]{2}{*}{ PAO1 } & \multicolumn{2}{|c|}{$105 \pm 18.9$} & \multicolumn{2}{|c|}{$91.0 \pm 15.6$} \\
\hline & $50 \mu g$ & $100 \mu g$ & $50 \mu g$ & $100 \mu g$ \\
\hline \multicolumn{5}{|l|}{ B Pili } \\
\hline PAK & $98.0 \pm 4.2$ & $112.9 \pm 6.0$ & $102.1 \pm 6.1$ & $112.0 \pm 4.1$ \\
\hline
\end{tabular}

A. Values are given as a percent of control (100\%) binding ( \pm SD) of bacteria to BECs. Bacteria were preincubated for $1 \mathrm{~h}$ at $37^{\circ} \mathrm{C}$ with 0 (control) or $50 \mu \mathrm{g} / \mathrm{ml}$ of SIM or TBM. The ratio of bacteria to BECs was 3700:1 and 2800:1 for PAK and PAO1 bacteria, respectively. B. Values are given as a percent of control $(100 \%)$ binding ( \pm SD) of pili to BECs. The concentration of pili was $5 \mu \mathrm{g} / \mathrm{ml}$. Preincubations of pili with mucin were carried out for $1 \mathrm{~h}$ at $37^{\circ} \mathrm{C}$ before the addition of the mixture to suspensions of BECs. Pili binding was quantitated by immunoassay (see Methods). 
logic basis of the initial pathologic interaction between this microbe and the CF host remains obscure (44). Because we were unable in this study to demonstrate a selective or specific binding of nonmucoid $P$. aeruginosa to purified normal or $\mathrm{CF}$ mucins, we feel that some features of the hypothesis of Ramphal and Vishwanath (39) may require revision. This is particularly true of the notion that specific adherence of pili to carbohydrates of mucin is responsible for a 'selective tropism' of $P$. aeruginosa for the respiratory tract in cystic fibrosis.

\section{Acknowledgments}

We are grateful to Dr. Max Cohen, Department of Surgery, Graduate Hospital, Philadelphia, who supplied patient intestinal secretions for mucin preparation, Ms. Ann Robson, technologist (Department of Microbiology, Hospital for Sick Children) for assistance in isolating Pseudomonas aeruginosa strains from sputum samples, and Dr. W. Paranchych (Department of Microbiology, University of Alberta, Edmonton) for supplying well characterized PAO1 PAK, P1, and HD1 strains.

\section{References}

1. Woods, D. E., D. C. Straus, W. G. Johanson, Jr., V. K. Berry, and I. A. Bass 1980. Role of pili in adherence of Pseudomonas aeruginosa to mammalial buccal epithelial cells. Infect. Immun. 29:1146-1151.

2. Ramphal, R., J. C. Sadoff, M. Pyle, and J. D. Silipigni. 1984. Role of pili in the adherence of Pseudomonas aeruginosa to injured tracheal epithelium. Infect. Immun. 44:38-40.

3. Doig, P., T. Todd, P. A. Sastry, K. K. Lee, R. S. Hodges, W. Paranchych, and R. T. Irvin. 1988. Role of pili in the adhesion of Pseudomonas aeruginosa to human respiratory epithelial cells. Infect. Immun. 56:1641-1646.

4. Doig, P., P. A. Sastry, R. S. Hodges, K. K. Lee, W. Paranchych, and R. T. Irvin. 1990. Inhibition of adhesion of Pseudomonas aeruginosa to human buccal epithelial cells by monoclonal antibodies directed against pili. Infect. Immun. 58:124-132.

5. Krivan, H. C., V. Ginsburg, and D. D. Roberts. 1988. Pseudomonas aeruginosa and Pseudomonas cepacia isolated from cystic fibrosis patients bind specifically to gangliotetraosylceramide (asialo GM1) and gangliotriosylceramide (asialo GM2). Arch. Biochem. Biophys. 260:493-496.

6. Baker, N., G. C. Hansson, H. Leffler, G. Riise, and C. Svanborg-Eden. 1990. Glycosphingolipid receptors for Pseudomonas aeruginosa. Infect. Immun. 58:2361-2366.

7. Doig, P., W. Paranchych, P. A. Sastry, and R. T. Irvin. 1989. Human buccal epithelial cell receptors of Pseudomonas aeruginosa identification of glycoproteins with pilus binding activity. Can. J. Microbiol. 35:1141-1145.

8. Baltimore, R. S., C. D. C. Christie, and G. J. W. Smith. 1989. Immuno-histopathologic localization of Pseudomonas aeruginosa in lungs from patients with cystic fibrosis. Am. Rev. Respir. Dis. 140:1650-1661.

9. Nelson, J. W., M. W. Tredgett, J. K. Sheehan, D. J. Thornton, D. Notman, and J. R. W. Govan. 1990. Mucinophilic and chemotactic properties of Pseudomonas aeruginosa in relation to pulmonary colonization in cystic fibrosis. Infect. Immun. 58:1489-1495.

10. Plotkowski, M. C., G. Beck, J. M. Tournier, M. Bernardo-Filho, E. A. Marques, and E. Puchelle. 1989. Adherence of Pseudomonas aeruginosa to respiratory epithelium and the effect of leucocyte elastase. J. Med. Microbiol. 30:285293.

11. Viswanath, S., and R. Ramphal. 1984. Adherence of Pseudomonas aeruginosa to human tracheobronchial mucin. Infect. Immun. 45:197-202.

12. Viswanath, S., and R. Ramphal. 1985. Tracheobronchial mucin receptor for Pseudomonas aeruginosa: predominance of amino sugars in binding sites. Infect. Immun. 48:331-335.

13. Ramphal, R., N. Houdret, G. Lamblin, G. Strecker, and P. Roussel. 1987. Inhibition of adherence of Pseudomonas aeruginosa to respiratory mucin by milk oligosaccharides. Proc. IX Int. Symp. Glycoconj. G131. (Abstr.)

14. Paranchych, W., P. A. Sastry, D. Drake, J. R. Pearlstone, and L. B. Smillie 1985. Pseudomonas pili. Studies on antigenic determinants and mammalian cell receptors. Antibiot. Chemother. 36:49-57.

15. Bradley, D. L., and T. L. Pitt. 1974. Pilus dependence of four Pseudomonas aeruginosa bacteriophages with non-contractile tails. J. Gen. Virol. 23:115.

16. Pasloske, B. L., P. A. Sastry, B. B. Finlay, and W. Paranchych. 1988. Two unusual pilin sequences from different isolates of Pseudomonas aeruginosa.J. Bacteriol. 170:3738-3741.

17. Doig, P. 1989. Characterization of the pilus of Pseudomonas aeruginosa: demonstration of an epithelial binding domain within the pilin. Ph.D. thesis. University of Toronto, Canada.

18. McEachran, D. W., and R. T. Irvin. 1985. Adhesion of Pseudomonas aeruginosa to human buccal epithelial cells: evidence for two classes of receptors. Can. J. Microbiol. 31:563-569.

19. Carlstedt, I., H. Lindgren, J. K. Sheehan, U. Ulmsten, and L. Wingerup. 1983. Isolation and characterization of human cervical mucus glycoproteins. Biochem. J. 211:13-22.

20. Mantle, M., and A. Allen. 1978. A colorimetric assay for glycoproteins based on the periodic acid/schiff stain. Biochem. Soc. Trans. 6:607-609.

21. Mantle, M., G. G. Forstner, and J. F. Forstner. 1984. Biochemical characterization of the component parts of intestinal mucin from patients with cystic fibrosis. Biochem. J. 224:345-354.

22. Wesley, A., J. F. Forstner, and G. G. Forstner. 1983. Structure of intestinal mucus glycoprotein from human post-mortem or surgical tissue: interfaces from correlation analysis of sugar and sulfate composition of individual mucins. Carbohydr. Res. 115:151-163.

23. Heinrikson, R. I., and S. C. Meredith. 1984. Amino acid analysis by reverse phase high performance liquid chromatography: precolumn derivatization with phenylisothiocyanate. Anal. Biochem. 136:65-74.

24. Hardy, M. R., R. R. Townsend, and C. L. Yuan. 1988. Monosaccharide analysis of glycoconjugates by anion exchange chromatography with pulsed amperometric detection. Anal. Biochem. 170:54-62.

25. Slomiany, A. B., B. L. Slomiany, A. Witas, M. Aono, and L. J. Newman. 1983. Isolation of fatty acids covalently bound to the gastric mucus glycoprotein of normal and cystic fibrosis patients. Biochem. Biophys. Res. Commun. 113:286-293.

26. Bhattacharyya, S. N., B. Kaufman, A. Khorrami, J. I. Enriquez, and B. Manna. 1988. Fibronectin: source of mannose in a highly purified respiratory mucin. Inflammation. 12:433-446.

27. Chadee, K., W. A. Petri, Jr., D. J. Innes, and J. I. Ravdin. 1987. Rat and colonic mucins bind to and inhibit adherence lectin of Entamoeba histolytica. J. Clin. Invest. 80:1245-1254.

28. Smith, P. K., R. I. Krohn, G. I. Hermanson, A. K. Mallia, I. H. Gartner, M. D. Provenzano, E. K. Fujimoto, N. M. Goeke, B. J. Olson, and D. C. Klenk. 1985. Measurement of protein using bicinchonic acid. Anal. Biochem. 150:7685 .

29. Paranchych, W., P. A. Sastry, L. S. Frost, M. Carpenter, G. D. Armstrong, and T. H. Watts. 1979. Biochemical studies of pili isolated from Pseudomonas aeruginosa strain PAO. Can. J. Microbiol. 25:1175-1181.

30. Laux, D. C., E. F. McSweegan, and P. S. Cohen. 1984. Adhesion of enterotoxigenic Escherichia coli to immobilized intestinal mucosal preparations: a model for adhesion to mucosal surface components. J. Microbiol. Methods. 2:27-39.

31. Sajjan, U. S., and J. Forstner. 1990. Characteristics of binding of Escherichia coli serotype 0157:H7 strain CL-49 to purified intestinal mucin. Infect. Immun. 58:860-867.

32. Sorenson, K., and U. Brodbeck. 1986. Assessment of coating-efficiency in ELISA plates by direct protein determination. J. Immunol. Methods. 95:291293.

33. Engvall, E., and P. Perlmann. 1971. Enzyme-linked immunosorbent assay (ELISA). Quantitative assay of immunoglobulin G. Immunochemistry. 8:871874.

34. Rosenberg, J., S. Pahlman, M. Glad, and S. Hjerten. 1975. Hydrophobic interaction chromatography on non-charged sepharose derivatives. Binding of a model protein related to ionic strength, hydrophobicity of the substituent and degree of substitution (determined by NMR). Biochim. Biophys. Acta. 412:5161 .

35. Adams, M. H. 1959. Methods of study of bacterial viruses. In Bacteriophages. M. H. Adams, editor. Interscience Publishers Inc., New York. 443-452.

36. Ramphal, R., N. Houdret, L. Koo, G. Lamblin, and P. Roussel. 1989. Differences in adhesion of Pseudomonas aeruginosa to mucin glycopeptides from sputa of patients with cystic fibrosis and chronic bronchitis. Infect. Immun 57:3066-3071.

37. Weerkamp, A. H., H. C. Van Der Mei, and J. W. Slot. 1987. Relationship of cell surface morphology and composition of Streptococcus salivarius $\mathrm{K}^{+}$to adherence and hydrophobicity. Infect. Immun. 55:438-445.

38. Ramphal, R., and M. Pyle. 1983. Evidence for mucins and sialic acid as receptors for Pseudomonas aeruginosa in the lower respiratory tract. Infect. Immun. 41:339-344.

39. Ramphal, R., and S. Viswanath. 1987. Why is Pseudomonas the colonizer and why does it persist. Infection. 15:281-287.

40. Garber, N., N. Sharon, D. Shohet, J. S. Lam, and R. J. Doyle. 1985. Contribution of hydrophobicity to hemagglutination reactions of Pseudomonas aeruginosa. Infect. Immun. 50:336-337.

41. Panjwani, N., T. S. Zaidi, J. E. Gigstad, F. B. Jungalwala, M. Barza, and J. Baum. 1990. Binding of Pseudomonas aeruginosa to neutral glycosphingolipids of rabbit corneal epithelium. Infect. Immun. 58:114-118.

42. Ramphal, R., C. Guay, and G. B. Pier. 1987. Pseudomonas aeruginosa adhesins for tracheobronchial mucin. Infect. Immun. 55:600-603.

43. Paranchych, W., and L. S. Frost. 1988. The physiology and biochemistry of pili. Adv. Microb. Physiol. 29:53-114.

44. Pitt, T. L. 1986. Biology of Pseudomonas aeruginosa in relation to pulmonary infection in cystic fibrosis. J. Royal Soc. Med. 79(Suppl. 12):13-18. 